\title{
MAKALAH \\ MOTIVASI DAN KEPEMIMPINAN
}

DOSEN PENGAMPU : DRA. NURAENI GANI, MM

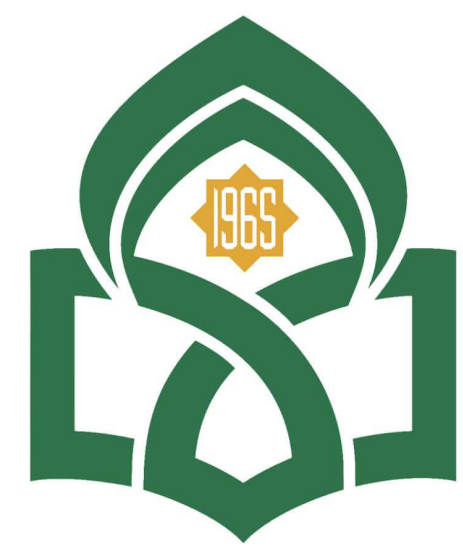

UNIVERSITAS ISLAM NEGERI

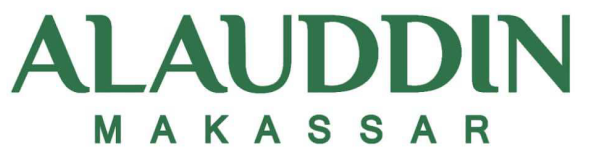

DISUSUN OLEH :

SRI DEVI AGUSTIN. SR

NIM. 90500121066

KELAS B

PROGRAM STUDI PERBANKAN SYARIAH

FAKULTAS EKONOMI DAN BISNIS ISLAM

UIN ALAUDDIN MAKASSAR 


\section{KATA PENGANTAR}

Dari jaman dahulu sampai jaman sekarang masyarakat sangat menginginkan sekali pemimpin yang adil, amanah, dan dapat mengembangkan negeri yang dipimpinnya. Selain itu tujuan dari apa yang telah disepakati bersama pun dapat tercapai, sehingga dapat tercipta masyarakat yang adil dan sejahtera. Sebagai seorang pemimpin selain harus bisa mengemban amanah dan berbuat adil, harus bisa memotivasi anggotanya yang kurang bersemangat melakukan aktivitas dalam kesehariannya, yang terkena musibah, ataupun masyarakat yang tidak mempunyai motivasi. Apabila masyarakat yang seperti itu didiamkan saja, maka akan menimbulkan efek negatif terhadap masyarakat lainnya, sehingga tujuan yang telah kita buat dan kita sepakati tidak akan tercapai. Meskipun sulit mencari seorang pemimpin yang seperti itu, akan tetapi apabila kita benar-benar mencari dan menyeleksi pemimpin dengan baik dan benar maka kita akan dapat pemimpin yang kita inginkan dan kita idam-idamkan.

Maka dari itu dalam makalah ini kami menjelaskan mengenai hubungan antara motivasi dengan kepemimpinan dan kami tahu makalah ini masih jauh dari kata sempurna jadi kami berharap pembaca bisa melengkapi kekurangan tersebut.

Jeneponto, 9 Desember 2021

Penyusun

SRI DEVI AGUSTIN. SR 


\section{DAFTAR ISI}

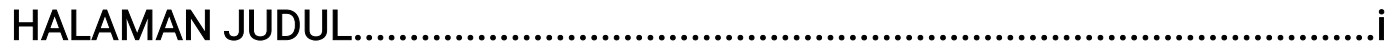

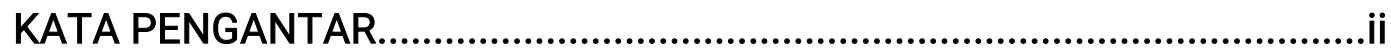

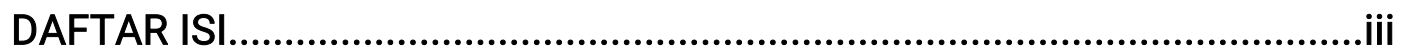

BAB 1 PENDAHULUAN

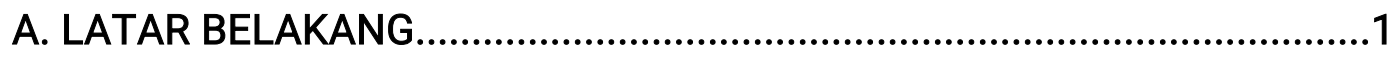

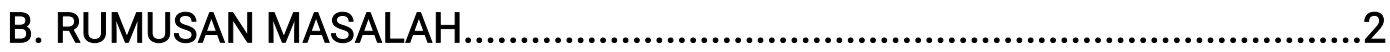

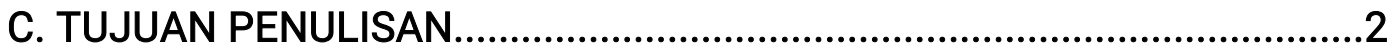

\section{BAB 2 PEMBAHASAN}

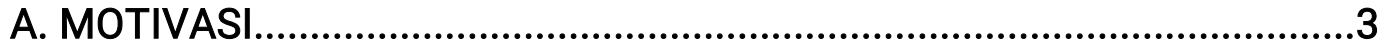

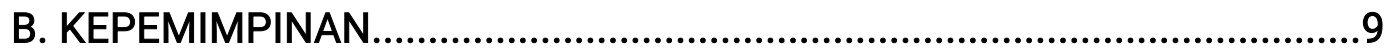

BAB 3 PENUTUP

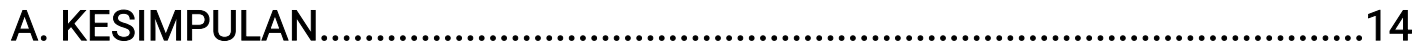

B. SARAN

DAFTAR PUSTAKA 


\section{BAB 1}

\section{PENDAHULUAN}

\section{A. LATAR BELAKANG}

Manusia adalah mahluk social yang tidak dapat hidup sendiri. Dalam hidup, manusia selalu berinteraksi dengan sesama serta lingkungan. Manusia hidup berkelompok baik dalam kelompok besar maupun berkelompok kecil.

Manusia adalah mahluk TUHAN yang paling tinggi dibandingkan mahluk TUHAN yang lainnya. Manusia dianugrahi kemampuan untuk berfikir, kemampuan untuk memilah mana ynag baik dan mana yang buruk. Dengan kelebihan itulah manusia seharusnya mampu mengelola lingkungan dengan baik.

Tidak hanya lingkungan yang perlu dikelola dengan baik, kehidupan social manusiapun perlu dikelola dengan baik. Untuk itulah dibutuhkan sumber daya manusia yang berkualitas. Sumber daya yang berjiwa pemimpin, paling tidak untuk memimpin untuk dirinya sendiri. Dengan berjiwa pemimpin manusia akan dapat mengelola diri, kelompok dan lingkungan dengan baik. Khususnya dalam penanggulangan maslah yang relative pelik dan sulit. Disinilah dituntut kerifan seseorang pemimpin dalam mengambil keputusan agar masalah dapat terselesaikan dengan baik.

Pemimpin dapat mempengaruhi moral, kepuasan kerja, keamanan, kualitas kehidupan kerja dan terutama tingkat prestasi suatu organisasi. Kemampuan dan ketrampilan kepemimpinan dan motovasi dalam pengarahan adalah factor penting efektivitas manajer. Bila organisasi dapat mengidentifikasikan kualitaskualitas yang berhubungan dengan kepemimpinan, kemampuan untuk menyeleksi pemimpinpemimpin yang efektif akan meningkat, bila organisasi dapat mengidentifikasikan perilaku dan teknik-teknik kepemimpinan efektif organisasi, berbagai perilaku dan teknik tersebut akan dapat dipelajari.

Penilaian prestasi kerja (performance appraisal) adalah proses melalui mana organisasi-organisasi mengevaluasi atau menilai prestasi kerja pegawai. Kegiatan ini dapat memperbaiki keputusan-keputusan personalia danmemberikan umpan balik kepada para pegawai tentang pelaksanaan kerja mereka. Kegunaan-kegunaan penilaian prestasi kerja dapat dirinci sebagai berikut, perbaikan prestasi kerja, penyesuaian- 
penyesuaian kompensasi, keputusan-keputusan penempatan, kebutuhan latihan dan pengembangan, perencanaan dan pengembangan karier, penyimpangan-penyimpangan proses staffing, ketidakakuratan informasional, kesalahan desain pekerjaan, kesempatan kerja yang adil dan tantangan-tantangan eksternal (Handoko, 1997).Disamping faktor kepemimpinan, faktor motivasi yang akan mempengaruhi kinerja pegawai yang dimiliki seseorang adalah merupakan potensi, dimana seseorang belum tentu bersedia untuk mengerahkan segenap potensi yang dimilikinya untuk mencapai hasil yang optimal.

Analisis ilmiah tentang kepemimpinan berangkatbdari pemusatan perhatian pemimpin itu sendiri. Theory sifat berkembang, pertama kali di Yunani Kuno dan Romawi yang beranggapan bahwa pemimpin itu dilahirkan, bukan diciptakan yang kemudian theory ini dikenal dengan " The Greatma Theory". Dalam perkembangannya, theory ini mendapat pengaruh dari aliran perilaku pemikir psikolosi yang berpandangan bahwa sifat sifat kepemimpinan tidak seluruhnya dilahirkan akan tetapi juga dapat dicapai melalui pendidikan dan pengalaman.

\section{B.RUMUSAN MASALAH}

Dari latar belakang masalah yang penulis uraikan, banyak permasalahan tsb antara lain :

1. Bagaimana hakikat menjadi seorang pemimpin?

2. Adakah teori teori untuk menjadi pemimpin yang baik?

3. Apakah Motivasi itu?

\section{TUJUAN PENULISAN}

Adapun tujuan penulisan Makalah ini adalah

1. Melatih mahasiswa menyusun paper (makalah) dalam upaya lebih meningkat pengetahuan dan kreatifitas mahasiswa.

2. Agar mahasiswa lebih memahami dan mendalami pokok bahasan khususnya tentang motivasi dan kepemimpinan. 


\section{BAB 2}

\section{PEMBAHASAN}

\section{A. MOTIVASI}

\section{Hakikat Dan Pengertian Motivasi}

Motivasi adalah proses yang menjelaskan intensitas, arah, dan ketekunan seorang individu untuk mencapai tujuannya. Tiga elemen utama dalam definisi ini adalah intensitas, arah, dan ketekunan.

Arti motivasi adalah alasan yang mendasari sebuah perbuatan yang dilakukan oleh seorang individu. Seseorang dikatakan memiliki motivasi tinggi dapat diartikan orang tersebut memiliki alasan yang sangat kuat untuk mencapai apa yang diinginkannya dengan mengerjakan pekerjaannya yang sekarang. Berbeda dengan motivasi dalam pengertian yang berkembang di masyarakat yang seringkali disamakan dengan semangat, seperti contoh dalam percakapan "saya ingin anak saya memiliki motivasi yang tinggi". Statemen ini bisa diartikan orang tua tersebut menginginkan anaknya memiliki semangat belajar yang tinggi. Maka, perlu dipahami bahwa ada perbedaan penggunaan istilah motivasi di masyarakat. Ada yang mengartikan motivasi sebagai sebuah alasan, dan ada juga yang mengartikan motivasi sama dengan semangat.

Dalam hubungan antara motivasi dan intensitas, intensitas terkait dengan seberapa giat seseorang berusaha, tetapi intensitas tinggi tidak menghasilkan prestasi kerja yang memuaskan kecuali upaya tersebut dikaitkan dengan arah yang menguntungkan organisasi. Sebaliknya elemen yang terakhir, ketekunan, merupakan ukuran mengenai berapa lama seseorang dapat mempertahankan usahanya.

1. Menurut Stanley Vance (1982): Motivasi pada hakikatnya adalah perasaan atau keinginan seseorang yang berada dan bekerja pada kondisi tertentu untuk melaksanakan tindakan-tindakan yang menguntungkan dilihat dari perspektif pribadi dan terutama organisasi.

2. Menurut T. Hani Handoko (2003): Motivasi adalah keadaan pribadi seseorang yang mendorong keinginan individu untuk melakukan kegiatan tertentu guna mencapai tujuan.

3. Menurut Robert Dubin (1985): Motivasi adalah kekuatan kompleks yang membuat 
seseorang berkeinginan memulai dan menjaga kondisi kerja dalam organisasi.

4. Menurut Prof. Dr. Sudarwan Danim (2004): Motivasi adalah setiap kekuatan yang muncul dari dalam diri individu untuk mencapai tujuan atau keuntungan tertentu di lingkungan dunia kerja atau di pelataran kehidupan pada umumnya.

5. Menurut A. Anwar Prabu Mangkunegara (2002): Motivasi adalah kondisi yang berpengaruh membangkitkan, mengarahkan dan memelihara perilaku yang berhubungan dengan lingkungan kerja.

Dari pengertian-pengertian motivasi yang telah disebutkan sebelumnya, maka dapat disimpulkan bahwa Motivasi merupakan suatu keadaan atau kondisi yang mendorong, merangsang atau menggerakan seseorang untuk melakukan sesuatu atau kegiatan yang dilakukannya sehingga ia dapat mencapai tujuannya.

\section{Unsur-Unsur Motivasi}

1) Tujuan.

Manusia adalah makhluk bertujuan, meski tidak ada manusia yang mempunyai tujuan yang benar-benar sama. Demikian juga sama halnya dengan organisasi. Idealnya semua manusia organisasional memiliki motivasi tinggi dan ada kesadaran dalam diri mereka bahwa tujuan organisasi adalah bagian dari tugas keorganisasian dan juga tujuan hidupnya. Manusia organisasional yang memiliki motivasi tinggi senantiasa sadar bahwa antara tujuan dirinya dengan tujuan organisasi sama sekali tidak terpisahkan atau kalaupun terpisah, tidak terlalu senjang. Sadar bahwa dia membutuhkan organisasi, dan sadar pula bahwa organisasi membutuhkan dirinya.

2) Kekuatan dari Dalam Diri Individu.

Manusia adalah insan yang memiliki energi, apakah itu energi fisik, otak, mental dan spiritual dalam arti luas. Kekuatan ini berakumulasi dan menjelma dalam bentuk dorongan batin seseorang untuk melakukan sesuatu dengan baik dan benar. Manusia organisasional bekerja dalam organisasi semata-mata karena rasa terpanggil untuk berbuat, tanpa mengingkari ada maksud-maksud yang ingin dicapai dari pekerjaan itu. Perilaku atau perbuatan sehari-hari dari manusia semacam ini berlangsung secara rutin, sengaja dan bersahaja.

3) Keuntungan.

Manusia bekerja ingin mendapatkan keuntungan adalah manusiawi, meski harus 
dihindari sikap yang hanya ingin bekerja manakala ada keuntungan langsung (direct profit) yang akan diperolehnya. Rasa dekat terhadap kebutuhan, keinginan memperoleh imbalan, rasa ingin meningkatkan diri dan seperangkat keinginan mencari keuntungan adalah bagian yang tidak terpisahkan dari keseluruhan aktivitas manusia. Namun keinginan untuk mendapatkan keuntungan ini akan menjadi bahaya bagi manusia organisasional, jika dia bekerja semata-mata karena dilihat dari dimensi untung-ruginya saja.

\section{Tipe-Tipe Motivasi.}

Secara umum motivasi dapat diklasifikasikan ke dalam empat (4) jenis:

1) Motivasi Positif

"Bekerjalah dengan baik! Kalau nanti target keuntungan tercapai, anda akan diberi bonus."

Statement ini merupakan bentuk nyata dari inisiatif membangkitkan manusia untuk mencari keuntungan-keuntungan tertentu. Manusia bekerja di dalam organisasi jika dia merasakan bahwa setiap upaya yang dilakukannya akan memberikan keuntungan tertentu. Dengan demikian, motivasi positif merupakan proses pemberian motivasi di mana hal itu diarahkan pada usaha untuk mempengaruhi orang lain agar dia bekerja secara baik dan antusias dengan cara memberikan keuntungan tertentu kepadanya.

2) Motivasi Negatif.

"Siapa saja yang sering terlambat datang atau sering membolos, akan dipotong gajinya.Dengan perilaku seperti itu, jangan berharap anda akan dipromosikan."

Ini merupakan contoh motivasi negatif. Motivasi negatif sering dikatakan sebagai motivasi yang bersumber dari rasa takut, misalnya, Jika anda tidak bekerja akan muncul rasa takut dikeluarkan, takut tidak diberi gaji, dan takut dijauhi oleh rekan kerja.

Motivasi negatif yang berlebihan akan membuat organisasi tidak mampu mencapai tujuan. Personalia organisasi menjadi tidak kreatif, serba takut, dan serba terbatas geraknya.

3) Motivasi dari Dalam.

"Saya bekerja karena terpanggil untuk itu! Ada atau tidak ada pimpinan di tempat, saya akan tetap bekerja sesuai dengan target dan tanggung jawab saya!" 
Statement ini mencerminkan kuatnya motivasi dari dalam yang terkandung pada diri karyawan. Motivasi dari dalam timbul pada diri pekerja waktu dia menjalankan tugastugas atau pekerjaan dan bersumber dari dalam diri pekerja itu sendiri. Dengan demikian berarti juga bahwa kesenangan pekerja muncul pada waktu dia bekerja dan dia sendiri menyenangi pekerjaan itu. Manusia seperti ini jarang cingcong atau menggerutu. Baginya bekerja adalah suatu kewajiban, bagaikan makan sebagai kebutuhan..

4) Motivasi dari Luar.

Motivasi dari luar adalah motivasi yang muncul sebagai akibat adanya pengaruh yang ada di luar pekerjaan dan dari luar diri pekerja itu sendiri. Motivasi dari luar biasanya dikaitkan dengan imbalan.

\section{Pendorong Motivasi}

Motivasi seseorang sering kali dipengaruhi oleh dua hal berikut.

1) Seberapa mendesaknya suatu kebutuhan. Misalnya, kita merasa lapar, namun harus menyelesaikan satu tugas dengan segera. Kalau kita merasa sangat lapar, kita akan makan. Tapi bila kita hanya sedikit merasa lapar, kita akan memilih untuk menyelesaikan tugas.

2) Anggapan bahwa suatu tindakan akan memenuhi suatu kebutuhan. Misalnya, ada dua kebutuhan yang mendesak -- keinginan untuk menyelesaikan tugas atau makan. Persepsi tentang bagaimana kita memandang dua kebutuhan tersebut sangat menentukan mana yang akan diprioritaskan. Kalau kita berpikir bahwa kita bisa dipecat karena tugas tidak selesai, kita akan mengorbankan waktu makan siang untuk mengerjakannya. Sebaliknya, jika kita merasa tidak akan mendapat masalah walaupun pekerjaan itu tidak selesai, kita akan pergi untuk makan siang.

Orang dapat termotivasi karena kepercayaan, nilai, minat, rasa takut, dan sebagainya. Diantaranya adalah faktor internal seperti kebutuhan, minat, dan kepercayaan. Faktor lainnya adalah faktor eksternal, misalnya bahaya, lingkungan, atau tekanan dari orang yang dikasihi. Tak ada proses yang mudah dalam motivasi -- kita harus selalu terbuka dalam memandang orang lain.

\section{Menjadi Motivator Yang Baik}


Adalah penting bagi seorang pemimpin untuk mengetahui bagaimana cara memotivasi karyawannya. MM Feinberg menjabarkan beberapa tindakan yang tidak memotivasi orang lain.

1) Meremehkan bawahan. Tindakan ini bisa membunuh rasa percaya diri dan inisiatif karyawan.

2) Mengkritik karyawan di depan karyawan lain. Tindakan ini pun bisa merusak hubungan yang sudah terbina baik.

3) Memberi perhatian setengah-setengah atau tidak memerhatikan karyawan. Kalau seorang pemimpin tidak memedulikan karyawannya, maka rasa percaya dirinya akan luntur.

4) Memerhatikan diri sendiri. Pemimpin yang seperti ini dianggap egois dan hanya memanipulasi karyawan untuk kepentingannya sendiri.

5) Menganak emaskan seorang karyawan. Tindakan ini sebaiknya juga tidak dilakukan, karena bisa merusak moral karyawan lain.

6) Tidak mendorong karyawan untuk berkembang. Kalau karyawan merasa bahwa bos juga ikut berjuang bersama, mereka akan sangat termotivasi. Informasikan kesempatan yang ada dan jangan pernah mengekang minat para karyawan.

7) Tidak memedulikan hal-hal kecil. Apa yang nampaknya kecil bagi Anda, mungkin saja sangat penting untuk karyawan.

8) Merendahkan karyawan yang kurang terampil. Seorang pemimpin memang wajib menolerir ketidakmampuan karyawannya, namun harus hati-hati dalam menangani permasalahan yang ditimbulkan agar tidak sampai mempermalukan karyawannya.

9) Ragu-ragu dalam mengambil keputusan. Atasan yang ragu-ragu mengakibatkan kebimbangan di seluruh organisasi.

Sesungguhnya, cara yang paling baik untuk memotivasi karyawan adalah melibatkan mereka dalam proses pengambilan keputusan. Saran, rekomendasi, dan kritik adalah pendorong yang paling efektif dan sangat memotivasi organisasi yang berani menerapkannya. 


\section{B. KEPEMIMPINAN}

\section{Hakikat Dan Pengertian Kepemimpinan}

Dalam kehidupan sehari hari baik dilingkunga keluarga, organisasi, perusahaan sampai dengan pemerintahaan sering kita dengar sebutan pemimpin, kepemimpinan serta kekuasaa. Ketiga kata tersebut memang memiliki hubungan yang berkaitan satu sama lainnya.

Beberapa ahli berpendapat tentang pimpinan, beberapa diantaranya :

1. Menurut Drs. H Malayu S.P Hasibuan adalah seseorang dengan wewenagn kepemimpinannya mengarahkan bawahannya untuk mengerjakan sebagian dari pekerjaannya dalam mencapai tujuan.

2. Menurut Robert Tanembuan pemimpin adalah mereka yang engggunakan wewenang formal untuk mengorganisasikan, mengarahkan, mengontrol para bawahan yang bertanggung jawab agar semua bagian pekerjaan dikoordinasikan demi mencapai tujuan.

3. Menurut Prof. Maccoby, pemimpin pertama tama seseorang yang mampu menumbuhkan dan mengembangkan segala yang terbaik dalam diri para bawahannya. Pemimpin yang baik untuk masa kini adalah orang yang religious dalam artian menerimakepercayaan etnis dan moral dari berbagai agama secara kumulatif, kendatipun ia sendiri mungkin menolak ketentuan gaib dan ide keTuhanan yang berlainan.

4. Menurut Lao Tzu, pemimpin yang baik adalah seorang yang membantu mengembangan orang lain, sehingga akhirnya mereka tidak lagi memerlukan pemimpinannya.

5. Menurut Davis and Filley, Pemimpin adalah seseorang yang mendidikan suatu posisi manajemen atau sesorang yang melakukan suatu pekerjaanmemimpin.

6. Sedangkan menurut Pancasila pemimpin haarus bersikap sebagai pengasuh yang mendorong, menuntun dan membimbing asuhannya.

Dengan kata lain, beberapa asas utamadari kepemimpinan Pancasila adalah :

1. Ing-Ngarsa Sung Tuladha : pemimpin harus mampu dengan sifat dan perbuatannya menjadikan dirinya pola anutan dan ikutan bagi orang orang yang dipimpinnya.

2. Ing-Madya Mangun Karsa : pemimpin harus mampu membangkitkan semangat dan 
berkreasi pada orang orang yang dibimbinya.

3. Tut Wuri Handayani : pemimpin harus mampu mendorong orang orang yang diasuhnya berani berjalan didepan dan sanggup bertanggung jawab.

Dari sebegitu banyak definisi mengenai pemimpin dapat disimpulkan bahwa pemimpin adalah orang yang mendapat amanah serta memiliki sifat, sikap dan gaya yang baik untuk menguru atau mengatur orang lain.

Kepemimpinan adalah kemampuan sesorang mempengaruhi atau memotivasi orang lain untuk melakukan sesuatu sesuai tujuan bersama. Kepemimpinan meliputi proses mempengaruhi dalam menentukan tujuan organisasi, memotivasi perilaku pengikut untuk mencapai tujuan, mempengaruhi untuk memperbaiki kelompok dan budayanya.

Dari batasan tersebut diatas, dapat diketahui bahwa kepemimpinan atau memimpin adalah usaha untuk mengerakkan orang lain ataupun bawahan yang dipimpin, supaya mereka dapat bekerja sama sama menuju tujuan yang diinginkan bersama dan yang dianggap penting bagi mereka. Jadi. Kepemimpinan itu dapat timbul kapan saja dan dimana saja, Apabila ada unsure unsure sebagai berikut :

1. Ada orang yang dipengauhin atau anggota, bawahan, pengikut, kelompok orang yang mau diperintah dan dikomandikan.

2. Ada orang yang mempengaruhi atau memimpin, pemberi komando, dan pembimbing.

3. Ada pengarahan kepada suatu tujuan oleh orang yang mempengaruhi atau memimpin.

Selain memperhatikan unsure unsure diatas, terdapat pula tiga hal yang perlu diperhatikan dalam kepemimpinan, antara lain :

1. Seorang pemimpin harus dapat mendistribusikan kekuasaanya kepada orang orang kepercayaanya dengan mengangkat orang orang yang tepat untuk menjadi kepala kepala bagian dalam perusahaan.

2. Seorang pemimpin harus bias memimpin bawahannya agar aktivitas perusahaan berjalan lancer.

3. Seorang pemimpin harus dapat menjadi contoh/teladan bagi bawahannya sehingga semua pekerjaan dapat pelaksanaan sesuai dengan apa yang diinginkan oleh perusahaan. 
2. Jenis Jenis Kepemimpinan

Dr. George R Terry, Phd. Mengemukakan berbagai jenis kepemimpinan yaitu sebagai berikut :

1. Kepemimpinan personal (personal leadership type).

2. Kepemimpinan nonpersonal (nonpersonal leadership type).

3. Kepemimpinan otoriter (authoritarian leadership type).

4. Kepemimpinan demokrasi (democratic leadership type).

5. Kepemimpinan kebapakan (paternalistic leadership type).

6. Kepemimpinan bakat (indogeneous leadership type).

Keith Devis merumuskan 4 sifat umum yang berpengaruh terhadap keberhasilan kepemimpinan organisasi, antara lain :

1. Kecerdasan.

2. Kedewasaan Dan Keluasan Hubungan Social.

3. Motivasi Diri Dan Dorongan Berperstasi.

4. Sikap Hubungan Kemanusiaan.

\section{Ciri-Ciri Seorang Pemimpin}

Kebanyakan orang masih cenderung mengatakan bahwa pemimipin yang efektif mempunyai sifat atau ciri-ciri tertentu yang sangat penting misalnya, kharisma, pandangan ke depan, daya persuasi, dan intensitas. Dan memang, apabila kita berpikir tentang pemimpin yang heroik seperti Napoleon, Washington, Lincoln, Churcill, Sukarno, Jenderal Sudirman, dan sebagainya kita harus mengakui bahwa sifat-sifat seperti itu melekat pada diri mereka dan telah mereka manfaatkan untuk mencapai tujuan yang mereka inginkan.

\section{Tugas-Tugas Seorang Pemimpin}


Menurut pandangan Prof. Dr, H. Arifin Abdurahman, tugas seorang pimpinan yang utama sebagai berikut :

1. Mengantarkan

2. Mendidik

3. Mengetuai

4. Memberikan bimbingan dan pimpinan yang baik

5. Memelopori

6. Mengerakkan bawahan.

7. Memberi petunjuk

Adapun tugas tugas seorang pemimpin yang dikemukakan oleh Prof. Dr. Sarwono Prawirojo sebagai berikut :

1. Menerjemahkan (menyampaikan) dan merancang serta memimpin pelaksanaan putusan putusan yang diambil oleh pihak atasan.

2. Mengatur prosedur dan tata tertib pekerjaan dari mereka yang bekerja di bawahnya.

3. Mengawasi kemajuan dalam pekerjaan dibawah pimpinannya.

4. Mengatur koordinasi antara usaha usaha dibawah pimpinannya.

5. Mempercayaka (menyerahkan) beberapa wewenag tanggung jawab kepada orang bawahannya.

\section{Keterampilan Kepemimpinan}

Ada tiga keterampilan kepemimpinan, antara lain :

1. Technical Skills, berarti suatu kemampuanyang dimiliki oleh seorang pemimpin untuk melaksanakan suatu pekerjaan. Walupun seorang wirausaha merupakan pemimpin yang dapat menyuruh orang lain mengerjakan suatu pekerjaan, namun dia harus mampu melaksanakan pekerjaan yang dilakukan oleh karyawan.

2. Human Skills, bererti kemampuan untuk bekerja sama dan membangun tim kerja bersama orang lain. 
3. Conceptual Skills, (keterampilan konsep), berarti seorang wirausaha harus mampu berfikir dan mengungkapkan pemikirannya dalam bentuk kerangka kerja dan konsep konsep lain dalam memudahkan pekerjaan.

\section{Kepemimpinan Karismatik}

Max Weber, seorang sosiolog, adalah ilmuan pertama yang membahas kepemimpinan karismatik. Lebih dari seabad yang lalu, ia mendefinisikan karisma (yang berasal dari bahasa Yunani yang berarti "anugerah") sebagai "suatu sifat tertentu dari seseorang, yang membedakan mereka dari orang kebanyakan dan biasanya dipandang sebagai kemampuan atau kualitas supernatural, manusia super, atau paling tidak dayadaya istimewa. Kemampuan-kemampuan ini tidak dimiliki oleh orang biasa, tetapi dianggap sebagai kekuatan yang bersumber dari yang Ilahi, dan berdasarkan hal ini seseorang kemudian dianggap sebagai seorang pemimpin. 


\section{BAB 3}

\section{PENUTUP}

\section{A. KESIMPULAN}

\section{MOTIVASI DAN KEPEMIMPINAN}

Motivasi adalah perpaduan antara keinginan dan energi untuk mencapai tujuan tertentu. Memengaruhi motivasi seseorang berarti membuat orang tersebut melakukan apa yang kita inginkan. Karena fungsi utama dari kepemimpinan adalah untuk memimpin, maka kemampuan untuk memengaruhi orang adalah hal yang penting.

Rahasia utama kepemimpinan adalah kekuatan terbesar seorang pemimpin bukan dari kekuasaannya, bukan kecerdasannya, tapi dari kekuatan pribadinya. Seorang pemimpin sejati sealalu bekerja keras memperbaiki dirinya sebelum sibuk memperbaiki orang lain. Pemimpin bukan sekedar gelar atau jabatan yang diberikan dari luar melainkan sesuatu yang tumbuh dan berkembang dari dalam diri sesorang. Kepemimpinan lahir dari sesorang. Kepemimpinan lahir dari proses internal.

Kepemimpinan dan motivasi merupakan dua hal yang berbeda, meski memiliki tautan dalam konteks kerja dan interaksi antar-manusia organisasional. Keith Davis mengemukakan bahwa tanpa kepemimpinan, organisasi hanya merupakan kelompok manusia yang kacau, tidak teratur, dan tidak akan dapat melahirkan perilaku bertujuan. Kepemimpinan adalah faktor manusiawi yang mengikat suatu kelompok bersama dan memberinya motivasi menuju tujuan-tujuan tertentu, baik dalam jangka pendek maupun jangka panjang. Ini berarti antara kepemimpinan dengan motivasi memiliki ikatan yang kuat.

Dari rumusan tadi, keterkaitan antara kepemimpinan dengan motivasi dapat dianalisis sebagai berikut:

1. Tanpa kepemimpinan, organisasi tidak lain adalah sekelompok manusia yang kacau.

Manusia organisasional, baik dalam kapasitas masing-masing dan terutama sebagai anggota kelompok, dituntut dapat memacu upaya pencapaian tujuan organisasi yang sekaligus bagian dari tujuan dirinya. Kehadiran pemimpin memungkinkan manusia organisasional dimotivasi untuk dapat bekerja secara efektif dan efisien. Kelompok 
dengan sistem yang kurang padu dapat menurunkan produktifitas organisasi. Atas dasar itu, manusia organisasi perlu diarahkan dan dimotivasi oleh pemimpinnya agar dapat bekerja secara efektif dan efisien, dengan akuntabilitas tertentu.

2. Kepemimpinan berkaitan dengan kepengikutan.

Kepengikutan (followership) adalah bagian yang paling dalam usaha melahirkan perilaku organisasi yang sesungguhnya. Bahkan ada yang mengatakan bahwa pada hakikatnya kepemimpinan adalah kepengikutan (leadership is follower). Istilah ini adakalanya diberi makna luas, bahwa pemimpin yang baik dihasilkan dari pengikut yang baik. Manusia pengikut di sini tidak dapat dipersepsi sebagai robot, Melainkan mereka adalah manusia biasa yang memiliki perasaan, kebutuhan, harapan, dan aspek manusiawi lainnya. Tanpa pemahaman terhadap aspek-aspek manusiawi yang dipimpin, kepemimpinan akan gagal.

3. Kepemimpinan mengandung arti kemampuan memotivasi.

Kompetensi bawahan antara lain tercermin dari motivasi kerjanya. Dia bekerja disebabkan oleh dua kemungkinan, yaitu benar-benar terpanggil untuk berbuat atau karena diharuskan untuk melakukan tugas-tugas itu. Banyak faktor yang mempengaruhi motivasi manusia dalam bekerja, antara lain bahwa manusia mempunyai seperangkat kebutuhan, mulai dari kebutuhan yang paling dasar (biologis) sampai kepada taraf kebutuhan paling tinggi, aktualisasi diri. Salah satu faktor yang mempengaruhi motivasi kerja seseorang adalah gaya kepemimpinan. Dengan demikian, kepemimpinan dapat pula berarti kemampuan memberi motivasi kepada bawahan.

\section{B. SARAN}

Sangat diperlukan sekali jiwa kepemimpinan pada setiap pribadi manusia dan motivasipun begitu. Jiwa kepemimpinan itu perlu selalu dipupuk dan dikembangkan, paling tidak untuk memimpin diri sendiri. Jika saja Indonesia memiliki pemimpin dan motivasi yang sangat tangguh tentu akan menjadi luar biasa. Karena jatuh bangun kita tergantung dari pemimpin. Pemimpin memimpin pengikut mengikuti jika pemimpin sudah tidak bisa memimpin dengan baik, cirinya adalah pengikut tidak mau lagi mengikuti. Oleh karena itu kualitas kita tergantung kualitas pemimpin kita. Maikin kuat yang memimpin maka makin kuat pula yang dipimpin. 


\section{DAFTAR PUSTAKA}

Ardana, Komang; Mujiati, Ni Wayan; Ayu Sriathi, Anak Agung. Perilaku Keorganisasian. 2009. Yogyakarta. Edisi ke-2. Graha Ilmu. xii=208 hlm, 1 jil. : $23 \mathrm{~cm}$.

Arifin, Syamsul. Leadership Ilmu dan Seni Kepemimpinan. 2012. Jakarta. Mitra Wacana Media. 1 jil, $17 \times 24 \mathrm{~cm}$.

Davis, Keith. Jhon W. Newstrom. Perilaku dalam Organisasi. 1985. Gelora Aksara Pratama.

Hasibuan, Malayu. Manajemen Dasar, Pengertian, dan Masalah. 2014. Jakarta. Bumi Aksara.

Masmuh,Abdullah. Komunikasi Organisasi dalam prespektif Teori dan Praktek. 2010. Malang. Cet. 2. xvii, $322 \mathrm{hlm}$, Tab, $15 \mathrm{~cm}$.

Muhammad, as-Suwaidan Thariq, Faisal. Melahirkan Pemimpin Masa Depan. 2005. Jakarta. Gema Insani Press.

Rivai,Veithzal. Kiat Memimpin dalam Abad ke-21. 2004. Jakarta:PT Raja Grafindo Persada.

Solihin,Ismail. Pengatar Manajemen. 2009. Jakarta. Gelora Aksara Pratama. Erlangga.

Wibowo. Perilaku dalam Organisasi. 2014. Jakarta. Raja Grafindo Persada. 
Wirawan. Kepemimpinan: Teori, Psikologi, Perilaku Organisasi, Aplikasi dan Penelitian. 2013. Jakarta. Raja Grafindo Persada.

Tim Olah Naskah 2010, LKS Kewirausahaan untuk SMK untuk kelas X semester 1 dan 2. Jakarta Selatan: CV. Graha Pustaka. 